\author{
At-Turats \\ Jurnal Pemikiran Pendidikan Islam
}

journal homepage: http://jurnaliainpontianak.or.id/index.php/atturats

\title{
Pendidikan Islam Menuju Masyarakat Madani di Era Globalisasi (Suatu Ikhtiar Menghadapi Tantangan Masyarakat Ekonomi Asean/MEA)
}

\author{
Eko Nursalim \\ Dosen di Sekolah Tinggi Agama Islam Sangatta (STAIS) \\ Kutai Timur, Kalimantan Timur
}

\begin{abstract}
A B S T R A K
Education is a human effort to buil his personality based on community values and culture. Even the simplest community has education process. Islam education concept building and increasing human quality and moeslim community in globalization era refer to Al-Quran and As-sunnah as the true resources. So that, Islam education should be able to deliver human as madani community whose has hard skill and soft skill packaged by Islamic values that ready to face all the chllanges in ASEAN Econimic community (MEA) with strategic steps to actualize relevant islam identity in every era.
\end{abstract}

Key Words: Islam Education, Madani Community, ASEAN Economic Community

\section{PENDAHULUAN}

Islam sebagai sebuah agama memberikan konsep ajaran yang komprehensif dan integral, tidak hanya pada persoalan $u b u d i$ yah (ibadah) khusus seperti shalat, puasa dan lainnya, tetapi juga menyangkut kode etik sosial yang digunakan manusia sebagai perangkat penataan sosial yang diarahkan pada kemaslahatan manusia itu sendiri. Al Qur'an dan Hadits adalah representasi dari ajaran Islam yang komprehensif tersebut, yang di dalamnya memuat ajaran yang lengkap dalam berbagai aspek, ${ }^{1}$ tak terkecuali masalah keilmuan/pendidikan, bahkan Rasulullah Muhammad SAW menerima wahyu pertama juga berkenaan dengan masalah pendidikan.

\footnotetext{
${ }^{1}$ Harun Nasution, Islam Rasional, (Mizan, Bandung, 1995), hlm. 25
}

Pendidikan Islam jika dikaitkan dengan isu Masyarakat Ekonomi Asean (MEA), menggambarkan bahwa tantangan persaingan ekonomi berpengaruh terhadap sistem pendidikan khususnya pendidikan Islam. Di era MEA ini, seharusnya bangsa Indonesia mulai mengembangkan sistem pendidikan Islam yang mampu melahirkan manusiamanusia unggul, yaitu manusia yang memiliki daya saing unggul ditingkat regional, bahkan tingkat global. Oleh karena itu, sistem pendidikan Islam harus merespon perubahan zaman, dan siap menghadapi MEA dengan langkah-langkah strategis untuk mengaktualisasikan identitas Islam yang relevan di segala zaman.

Sebagai salah satu upaya mempersiapkan diri menghadapi era MEA ini, maka melalui pendidikan islam khususnya 
di Indonesia diharapkan mampu mengantarkan rakyat menjadi masyarakat madani (civil society) yang memiliki hard skill dan soft skill yang dikemas dalam nilai-nilai islami. ${ }^{2}$

\section{PENDIDIKAN ISLAM: ANTARA MASYARAKAT MADANI DAN GLOBALISASI}

Masyarakat madani merupakan konstruksi bahasa yang "Islami" yang mengacu pada kata al din, yang umumnya diterjemahkan sebagai agama, berkaitan dengan makna al tamaddun, atau peradaban. Keduanya menyatu ke dalam pengertian al madinah yang artinya kota. Dengan demikian, maka terjemahan masyarakat madani mengandung tiga hal, yakni agama, peradaban dan perkotaan. Di sini agama merupakan sumber, peradaban adalah prosesnya, dan masyarakat kota adalah hasilnya. ${ }^{3}$

Sedangkan civil society secara harfiah adalah terjemahan dari istilah Latin, Civilis Societas. Menurut Cicero (106-43 SM) Masyarakat sipil disebutnya sebagai sebuah masyarakat politik (Political Society) yang memiliki kode hukum sebagai pengaturan hidup. ${ }^{4}$ Jadi, secara semantik, istilah masyarakat madani agak kurang tepat disepadankan dengan istilah civil society. Meski kedua istilah tersebut secara parsial substantif memiliki kesamaan. Dan keduanya sangat relevan sebagai bahan kajian dalam

${ }^{2}$ Abdul Wadud Nafis, Prospek Ahli Ekonomi Syariah dalam menghadapi ASEAN Economic Community, (Iqtishoduna Vol. 4 No. 1, April 2014), hlm. 3

${ }^{3}$ M. Dawam Raharjo, Masyarakat Madani: Agama, Kelas Menengah dan Perubahan Sosial, (Pustaka LP3ES, Cet. ke - 1, Jakarta, 1999), hlm. 146

${ }^{4}$ M. Dawam Raharjo, Sejarah Agama dan Masyarakat Madani dalam Membongkar "Mitos" Masyarakat Madani, (Pustaka Pelajar, Yogyakarta, 2001), hlm. 18 upaya mencari paradigma masyarakat baru. Namun bila ditilik dari locus sejarah berkembangnya, kedua istilah tersebut secara pragmatik, berbeda. ${ }^{5}$

Jadi, akan lebih baik jika masyarakat madani dan civil society lebih banyak ditinjau dari pemaknaan secara filosofis karena akan lebih komprehensif, sekaligus untuk menghindari perdebatan maka kita perlu memberika wish bahwa dalam persoalan pengertian antara Masyarakat madani dan civil society "kira - kira" adalah sama. ${ }^{6}$

Sementara itu, globalisasi dapat dipahami berasal dari asal kata globe, yang berarti bola bumi. Istilah ini digunakan karena akselerasi penyebaran informasi yang luar biasa. Dalam waktu sekejap saja, melalui fasilitas teknologi komunikasi yang teramat canggih, arus informasi dari satu belahan bumi bisa menyebar secara merata ke seluruh bola bumi. Karena kenyataan inilah kita lalu seolah-olah menjadi bagian dari istilah-istilah itu. ${ }^{7}$

Globalisasi adalah sebuah term yang telah lama mewacana sampai sekarang ini, globalisasi masih terus menjadi materi perbincangan di kalangan ilmuwan dari varian disiplin keilmuan yang biasanya ditandai dengan kemajuan teknologi komunikasi informasi dan transportasi yang telah menghasilkan perubahan dalam kebudayaan dan peradaban manusia. Globalisasi selalu dihubungkan dengan modernisasi dan modernism. Para pakar budaya mengatakan bahwa ciri khas modernisasi dan manusia modern itu adalah tingkat berfikir, iptek, dan sikapnya terhadap penggunaan waktu dan penghargaan

${ }^{5}$ Ibid., hlm. 19

${ }^{6}$ Deny Suito. Membangun Masyarakat Madani. (Centre For Moderate Muslim Indonesia: Jakarta. 2006), hlm. 23

${ }^{7}$ Kuntowijoyo, Pengantar Ilmu Sejarah, (Yogyakarta: Yayasan Bintang Budaya. 1995), hlm.17 
terhadap karya manusia. ${ }^{8}$ Menurut Abuddin Nata ( 2003; 183) dari sudut peristilahan kata globalisaasi sebenarnya masih mengalami problem karena realitas serta subyektifitas pemakaian kata tersebut, namun globalisasi secara sederhana dapat ditunjukkan dalam bentuk perluasan skala, pengembangan wilayah, dan percepatan pengaruh dari arus dan pola-pola inter-regional dalam interaksi sosial. ${ }^{9}$

Berkaitan dengan masyarakat madani dan globalisasi, pendidikan Islam merupakan salah satu instrument dalam mempersiapkan insan-insan yang terampil yang mampu bersaing dalam pasar ekonomi khususnya pada Masyarakat Ekonomi Asean (MEA) dan kebutuhan pasar global pada umumnya. Misalnya, di tingkat Perguruan Tinggi Islam melalui penyediaan program studi yang dibutuhkan pasar domestik dan internasional, sampai yang menjadi trend bagi kebutuhan pasar global. Hal ini amat penting untuk dicermati, agar output pendidikan Islam benar-benar terjual dan bersaing di pasar global.

\section{KETERKAITAN PENDIDIKAN ISLAM DENGAN MASYARAKAT MADANI (CIVIL SOCIETY)}

Ada beberapa persamaan antara konsep Pendidikan Islam dengan masyarakat madani (civil society), di mana Pendidikan Islam bertujuan untuk menciptakan pribadipribadi yang bertaqwa, beretika-moral yang baik, yang dilandaskan pada ajaran-ajaran Islam yang bersumber dari Al Qur'an dan Hadits yang muara akhirnya adalah penciptaan manusia paripurna atau insan kamil. Se-

\footnotetext{
${ }^{8}$ M. Solly Lubis, Umat Islam Dalam Globalisasi, ( Jakarta: Gema Insani Press. 1997), hlm. 19

${ }^{9}$ Abuddin Nata, Kapita Selekta Pendidikan Islam, (Bandung: Angkasa, 2003), hlm.183
}

dangkan masyarakat madani (civil society) adalah kondisi di mana masyarakat mempunyai budi baik (beradab) yang dilandaskan sikap transcendental (berdasarkan agama) yang bersumber dari doktrin langit (wahyu/ ajaran Tuhan). ${ }^{10}$ Jadi, sangatlah jelas hubungan antara Pendidikan Islam dengan masyarakat madani (civil society), karena di satu sisi jika kita pahami bahwa Pendidikan Islam membentuk pribadi - pribadi yang beradab, maka follow up nya adalah terbentuknya masyarakat yang beradab pula.

Dapat diambil konklusi awal, setidaknya ada dua keterkaitan antara Pendidikan Islam dan masyarakat madani (civil society) yaitu:

\section{Keterkaitan fungsional}

Bahwa ada beberapa faktor atau lebih tepat sebagai unsur - unsur yang terdapat dalam pendidikan antara lain peserta didik, pendidik, alat dan lingkungan (masyarakat). ${ }^{11}$ Empat unsur awal dapat digolongkan sebagai (lembaga pendidikan) dan yang terakhir masyarakat itu sendiri. Jika, Pendidikan Islam sebagai nilai - nilai yang dapat diwujudkan secara kelembagaan misalnya lewat Pendidikan Agama Islam, maka tentunya Pendidikan Islam dengan sendirinya akan menjadi suplier tenaga ahli, atau lebih penting Sumber Daya Manusia (SDM) yang bermoral, beretika sosial atau dalam hal ini muslim muttaqin sebagaimana disebut di atas, sehingga nantinya dapat berguna bagi masyarakat yang menjadi "konsumen" pendidikan tersebut. Dan di satu sisi masyarakat bisa menjadi "produsen" bagi dunia pendidikan, yang secara sederhana bisa

\footnotetext{
${ }^{10}$ Deny Suito (2006). Membangun Masyarakat Madani, hlm. 30

${ }^{11}$ Sutari Imam Barnadib, Pengantar Ilmu Pendidikan Sistematis, (FIP-IKIP Yogyakarta, 2000), hlm. 39
} 
diwujudkan lewat tenaga pendidikan dan siswa yang merupakan anggota masyarakat itu sendiri. Hal tersebutlah menurut penulis yang dikatakan keterkaitan fungsional, karena antara masyarakat yang menginginkan masyarakat beradab (madani) terkait dengan Pendidikan Islam (lembaga) yang memang salah satu fungsinya mencetak individuindividu yang beradab (madani).

\section{Keterkaitan filosofik}

Pendidikan Islam adalah pendidikan yang didasarkan pada nash Al Qur'an dan Hadits. Jika kita pahami bahwa pendidikan sebagai peradaban manusia, maka dengan sendirinya kita dapat mengatakan bahwa proses pendidikan berarti juga aktifitas manusia itu sendiri dalam membuat sebuah kebudayaan dan peradaban. Maka sudah barang tentu nilai - nilai yang terkandung dalam Al Qur'an dan Hadits adalah prinsip yang harus selalu dipegang umat manusia, karena Al Qur'an dan Hadits sebagai kaidah nilai bagi setiap manusia, yang berarti untuk menciptakan masyarakat yang beradab tentunya harus dilandaskan pada ajaran yang baik dan benar.

Al Qur'an dan Hadits sebagai sumber Pendidikan Islam memberikan sebuah ajaran yang baik dan benar dalam aktifitas kehidupan masyarakat dalam membangun peradabannya. Dari sinilah tergambar jelas bahwa Al Qur'an dan Hadits sebagai sumber ilmu mengandung ajaran yang sangat komprehensif dan integral sehingga melebihi porsi layak untuk dijadikan landasan berpijak bagi setiap aktifitas manusia, bahkan kalau dalam bahasa penulis ajaran tersebut tidak hanya bagi umat Islam yang memang mengakui Al Qur' an dan Hadits sebagai sumber ajarannya tetapi bisa juga bagi kelompok non muslim, karena memang Islam dengan $\mathrm{Al}$
Qur'an dan Haditsnya diturunkan bagi "seru sekalian alam". ${ }^{12}$

Maka asumsi penulis inilah yang disebut keterkaitan filosofis, karena masyarakat (manusia) dalam peradabannya memerlukan sumber inspirasi, sumber pengakuan dan sandaran vertikal sehingga peradaban manusia pada dasarnya tidak hanya dalam konteks dapat dipertanggungjawabkan oleh akal fikiran manusia tetapi dapat dipertanggungjawabkan dalam dimensi ketuhanan yang memang diyakini mempunyai kebenaran absolut.

\section{SEKILAS POTRET SISTEM EKONOMI ISLAM}

Menurut ajaran Islam, semua kegiatan manusia termasuk kegiatan sosial dan ekonomi haruslah berlandaskan tauhid (keesaan Allah). Setiap ikatan atau hubungan antara seseorang dengan orang lain dan penghasilannya yang tidak sesuai dengan ajaran tauhid adalah ikatan atau hubungan yang tidak Islami. Dengan demikian realitas dari adanya hak milik mutlak tidak dapat diterima dalam Islam, sebab hal ini berarti mengingkari tauhid. Manurut ajaran Islam hak milik mutlak hanya ada pada Allah saja. Hal ini berarti hak milik yang ada pada manusia hanyalah hak milik nisbi atau relatif. Islam mengakui setiap individu sebagai pemilik apa yang diperolehnya melalui bekerja dalam pengertian yang seluas-luasnya, dan manusia berhak untuk mempertukarkan haknya itu dalam batas-batas yang telah ditentukan secara khusus dalam hukum Islam. Pernyataan-pernyataan dan batas-batas hak milik dalam Islam sesuai dengan kodrat manusia itu sendiri, yaitu dengan sistem keadilan dan sesuai dengan hak-

${ }^{12}$ Deny Suito (2006). Membangun Masyarakat Madani, hlm. 33 
hak semua pihak yang terlibat di dalamnya. ${ }^{13}$

Di dalam ajaran Islam terdapat dua prinsip utama, yakni pertama, tidak seorangpun atau sekelompok orangpun yang berhak mengeksploitasi orang lain; dan kedua, tidak ada sekelompok orangpun boleh memisahkan diri dari orang lain dengan tujuan untuk membatasi kegiatan sosial ekonomi di kalangan mereka saja. Islam memandang umat manusia sebagai satu keluarga, maka setiap manusia adalah sama derajatnya di mata Allah dan di depan hukum yang diwahyukannya. Konsep persaudaraan dan perlakuan yang sama terhadap seluruh anggota masyarakat di muka hukum tidaklah ada artinya kalau tidak disertai dengan keadilan ekonomi yang memungkinkan setiap orang memperoleh hak atas sumbangan terhadap masyarakat. Allah melarang hak orang lain, sebagaimana dijelaskan dalam Q.S. al-Syu'ara ayat 183 :

Artinya: Dan janganlah kamu merugikan manusia pada hak-haknya dan janganlah kamu merajalela di muka bumi dengan membuat kerusakan;

Dalam komitmen Islam yang khas dan mendalam terhadap persaudaraan, keadilan ekonomi dan sosial, maka ketidakadilan dalam pendapatan dan kekayaan bertentangan dengan Islam. Akan tetapi, konsep Islam dalam distribusi pendapatan dan kekayaan serta konsepsinya tentang keadilan sosial tidaklah menuntut bahwa semua orang harus mendapat upah yang sama tanpa memandang kontribusinya kepada masyarakat. Islam mentoleransi ketidaksamaan pendapatan sampai tingkat tertentu, karena setiap orang tidaklah

${ }^{13}$ Aji Dedi Mulawarman, Masa Depan Islam: Dari Paradigma Menuju Metodologi, (Jurnal Ekonomi Imanensi, Vol. 1 No. 1, September 2013), hlm. 5 sama sifat, kemampuan, dan pelayanannya dalam masyarakat. ${ }^{14}$

\section{PENDIDIKAN ISLAM MENUJU MASYARAKAT MADANI DI ERA GLOBALISASI: SUATU IKHTIAR MENGHADAPI TANTANGAN MASYARAKAT EKONOMI ASEAN (MEA)}

Suatu negara akan memiliki masyarakat yang berperadaban dalam hal ini penulis menyebut dengan masyarakat madani, salah satunya dapat terwujud sebagai bentuk hasil (out put) yang diperoleh melalui proses pendidikan Islam. Kaitannya dengan kehidupan era globalisasi, maka tidak bisa dielakkan lagi jika saat ini Indonesia sudah memasuki era Masyarakat Ekonomi Asean (MEA).

Dengan hadirnya ajang MEA ini, Indonesia memiliki peluang untuk memanfaatkan keunggulan skala ekonomi dalam negeri sebagai basis memperoleh keuntungan. Namun demikian, Indonesia masih memiliki banyak tantangan dan risiko-risiko yang akan muncul bila MEA telah diimplementasikan secara total. Dilihat dari sisi pendidikan dan produktivitas Indonesia masih kalah bersaing dengan tenaga kerja yang berasal dari Malaysia, Singapura, dan Thailand serta fondasi industri yang bagi Indonesia sendiri membuat Indonesia berada pada peringkat keempat di ASEAN. ${ }^{15}$ (Republika Online, 2013).

Oleh karena itu, para risk professional diharapkan dapat lebih peka terhadap fluktuasi yang akan terjadi agar dapat mengantisipasi risiko-risiko yang muncul dengan tepat.

\footnotetext{
${ }^{14} \mathrm{https}$ ://fixguy.wordpress.com/makalahmasyarakat-madani/

${ }^{15}$ Republika Online (2013), Indonesia Hanya Menduduki Peringkat Empat di ASEAN.
} 
Para pakar dan ahli ekonomi di Indonesia memberikan prediksi terkait dengan pasar global yang terjadi di negara-negara Asean, salah satunya Indonesia diharapkan mampu mempersiapkan diri dari segi hard skill dan soft skill. Misalnya, dari segi hard skill antara lain; mempersiapkan tenaga terampil dan profesional, memiliki pengetahuan dan pengalaman kerja yang sesuai, serta legalitas sertifikat pengakuan kerja, dan lain sebagainya. Sedangkan dari segi soft skill antara lain; mempersiapkan mental yang kuat, memiliki kecerdasan yang holistic yang mencakup kecerdasan intelektual, emosional, spiritual serta adverstional. Oleh karena itu, dengan banyaknya peluang dan tantangan yang dihadapi khususnya masyarakat Indonesia, pendidikan Islam harus mampu menguatkan sikap mental kemandirian individu, bukan sekadar pelatihan life skill dan hard skill saja, tetapi juga melatih jiwanya dengan mengoptimalkan soft skill agar memiliki mental yang kuat dalam menghadapi tantangan kehidupan di era globalisasi. Maka pendidikan Islam dengan dasar materi yang berlandaskan Al-Qur'an dan Hadits mencoba memberi solusi alternatif dari sisi pembentukan mental dengan menciptakan masyarakat madani (civil society) yang akan membentengi pribadi masyarakat Indonesia. Karena tidak bisa dipungkiri bahwa masyarakat Indonesia pada umumnya tidak semuanya siap menghadapi arus globalisasi pada MEA ini. ${ }^{16}$

Kaitannya dengan Masyarakat Ekonomi Asean (MEA), merunut pendapat Nurcholish Madjid (1949; 21) bahwa masyarakat madani (civil society) identik dengan masyarakat yang mempunyai peradaban mulia, yang mempunyai karakteristik antara lain;

${ }^{16}$ Tulus T.H Tambunan, Masyarakat Ekonomi ASEAN; peluang dan tantangan bagi UKM Indonesia, (Policy Paper No: 15 tahun 2013), hlm. 8
Semangat pluralisme, Tingginya sikap toleransi, Tegaknya prinsip demokrasi. ${ }^{17}$ Dari karakteristik tersebut dapat digunakan sebagai dasar pembentukan mental pribadi seseorang yang akan siap menghadapi tantangan arus globalisasi Masyarakat Ekonomi Asean (MEA).

\section{Semangat Pluralisme}

Berkenaan dengan masalah pluralisme, merupakan suatu unsur yang sangat asasi dalam masyarakat madani sebagaimana diletakkan dasar-dasarnya oleh Nabi, kita dapatkan dalam wacana masyarakat sipil (Indonesia) masih menunjukkan pemahaman yang dangkal dan kurang sejati. Istilah "pluralisme" sudah menjadi barang harian dalam wacana umum nasional. Namun dalam masyarakat ada tanda - tanda bahwa orang memahami pluralisme hanya sepintas lalu, tanpa makna yang lebih mendalam, tidak berakar dalam ajaran kebenaran.

Paham kemajemukan masyarakat atau pluralisme tidak cukup hanya dengan sikap mengakui dan menerima kenyataan masyarakat yang majemuk, tapi harus disertai dengan sikap yang tulus untuk menerima kenyataan kemajemukan itu sebagai bernilai positif, sebagai rahmat Tuhan kepada manusia, karena akan memperkaya pertumbuhan budaya melalui interaksi yang dinamis lewat pertukaran silang budaya yang beraneka ragam. Pluralisme harus dipahami sebagai "pertalian sejati kebhinekaan dalam ikatan ikatan keadaban." Bahkan Pluralisme adalah suatu keharusan bagi keselamatan umat ma-

\footnotetext{
${ }^{17}$ Nurcholish Madjid, "Masyarakat

Madani dan Investasi Demokrasi : Tantangan dan Kemungkinan" dalam Ahmad Baso, Civil Society Versus Masyarakat Madani, Arkeologi Pemikiran “'Civil Society” Dalam Islam di Indonesia, (Pustaka Hidayah,Cet. ke - 1, Bandung, 1999), hlm. 21.
} 
nusia, antara lain melalui mekanisme pengawasan dan pengimbangan yang dihasilkannya. ${ }^{18}$

Melalui pemahaman pluralisme adalah dapat dikatakan salah satu ciri khas masyarakat madani (civil society), merupakan pengemudi utama kemajuan dalam ilmu pengetahuan, masyarakat dan perkembangan ekonomi. Suatu negara tidak bisa melihat terwujudnya pluralisme politik yang sejati tanpa adanya pluralisme ekonomi. Untuk itu, suatu pemerintahan harus membangun terwujudnya pluralitas politik, partisipatori demokrasi, tidak berpihak pada salah satu kubu yang bertarung dalam perang pasar global antar negara-negara khususnya pada Masyarakat Ekonomi Asean (MEA). Berdasarkan pada kebijakan ini, maka prioritas utama dari pembangunan ekonomi adalah mengentaskan kemiskinan rakyat secara merata dan menyeluruh.

Jadi, dalam perwujudan masyarakat madani atau civil society adalah pluralisme lembaga - lembaga masyarakat sebagai penyeimbang institusi negara sangat dituntut. Merujuk pada peristiwa Piagam Madinah menjadi tonggak pertama kali diperkenalkannya umat manusia pada pluralisme, kebebasan, terutama dibidang agama dan ekonomi, serta tanggungjawab sosial dan politik, khususnya pertahanan. ${ }^{19}$

Dalam konteks yang lebih luas, pluralisme dipahami sebagai sesuatu yang normatif, karena kemajemukan sebagai suatu perbedaan adalah shahih, sehingga mau tidak mau motif yang kita kembangkan bukan untuk menghilangkan perbedaan yang ada, tetapi bagaimana menjadikan perbedaan -

\footnotetext{
${ }^{18}$ Ibid., hlm. 23

${ }^{19}$ Adnan Buyung Nasution, "Menuju Penguatan 'Civil Society", dalam Masyarakat Peradaban, (ILHAM, Semarang, 1997), hlm. 6.
}

perbedaan yang ada dalam segala hal seperti ideologi, kepercayaan, agama, suku, ras, warna kulit dan kepentingan diarahkan pada konsep mutualisme simbiosisme (saling mengisi atau saling membutuhkan).

\section{Tingginya Sikap Toleransi}

Belajar pada sejarah Rasulullah Muhammad SAW ketika memimpin Madinah, nilai-nilai toleransi dijadikan salah satu "asas" negara Madinah. Pluralitas yang ada di Madinah waktu itu dengan adanya pemeluk agama Yahudi dan Nasrani tentunya menjadikan nilai toleransi sebagai ajaran yang secara mutlak harus dilakukan, karena bagaimanapun juga Rasulullah tentunya ingin menunjukkan bahwa Islam sebagai agama rahmatan lil alamin dengan tidak memerangi kelompok minoritas, bahkan sebagai jaminan Rasulullah menjadikan nilai toleransi sebagai "konstitusi" yang termaktub dalam piagam Madinah. ${ }^{20}$

Kaitannya dengan tantangan pasar global pada era MEA ini, bahwa masyarakat Indonesia khususnya dalam bingkai masyarakat madani (civil society) harus mampu menciptakan ekonomi kreatif yang diharapkan dapat mengejar ketertinggalan dari sisi product, marketing dan lain sebagainya. Dalam perspektif ekonomi kreatif, toleransi dipahami sebagai kesediaan secara sadar, cerdas, dan terbuka untuk menerima masukan, saran, ide, bahkan perbedaan terutama yang berkaitan dengan rancang bangun dan desain sebuah produk ekonomi. toleransi mencakup pula kehendak secara sadar untuk memberikan atensi atau perhatian dan empati kepada gagasan atau ide yang datang dari luar meskipun tidak harus menerimanya. Dengan toler-

\footnotetext{
${ }^{20}$ Nurcholish Madjid (1999), Masyarakat Madani...., hlm. 25.
} 
ansi, kreativitas perekonomian yang diperoleh dari hasil olah pikir manusia dapat diperbarui secara terus-menerus, dan pembaruan hanya bisa terjadi jika terbuka pintu seluas-luasnya bagi masuknya nilai-nilai positif dari luar. ${ }^{21}$

\section{Tegaknya Prinsip Demokrasi}

Bicara tentang demokrasi, biasanya orang berbicara tentang interaksi antara negara dan civil society (masyarakat madani). Asumsinya adalah, jika civil society (masyarakat madani) terbentuk dengan baik maka demokrasi akan berlangsung dengan baik pula. Dengan demikian demokratisasi dipahami sebagai proses pemberdayaan civil society (masyarakat madani).

Selain itu, konsep masyarakat madani (civil society) yang berkaitan dengan kekuatan sosial yang demokratis, progresif dan terbuka. Maka untuk pembentukan masyarakat madani (civil society), perlu menjamin terjadinya proses demokratisasi, yang diselenggarakan melalui sistem perundang-undangan dan kelembagaan yang sesuai, serta peletakan landasan etik dan pengaturan hukum dari pola perilaku pemegang kekuasaan. ${ }^{22}$

Kaitannya masyarakat madani (civil society) dalam menghadapi era MEA ini, bahwa seluruh elemen masyarakat Indonesia hendaknya mampu memahami dalam menerapkan sikap demokrasi ekonomi yang berkaitan dengan pengertian kedaulatan rakyat di bidang ekonomi yaitu melalui serangkaian kegiatan produksi dalam sebuah sistem negara yang dikendalikan oleh semua masyarakat dan semuanya berada di bawah

${ }^{21}$ Tulus T.H Tambunan (2013), Masyarakat Ekonomi ASEAN.... hlm. 12

${ }^{22}$ M. Taufik Abdullah, "Di Sekitar Hasrat Ke Arah Masyarakat Madani”, dalam Membangun Masyarakat Madani Menuju Indonesia Baru Milenium Ketiga, (Pasca Sarjana UMM dan Aditya Media, Cet. ke-1, Yogyakarta, 1999), hlm. 71. pimpinan atau bisa jugamelalui pemilihan anggota-anggota masyarakat. Dalam sistem demokrasi ekonomi, masyarakat adalah komponen utama yang harus dimakmurkan, bukan hanya seorang individu saja. Negara Indonesia, merupakan salah satu negara yang menganut sistem demokrasi, begitu halnya dalam bidang ekonomi, Indonesia telah memanfaatkan sistem demokrasi ekonomi yang berdasarkan pada ketetapan Pancasila dan UUD 1945 serta GBHN, sehingga demokrasi ekonomi di Indonesia biasa disebut dengan "Sistem Ekonomi Berdasarkan Demokrasi Ekonomi Pancasila". ${ }^{23}$

\section{KESIMPULAN}

Eksistensi pendidikan Islam dalam era globalisasi ini memberikan banyak perubahan, terutama berkaitan dengan sikap dan mentalitas suatu bangsa. Indonesia, dengan Negara yang mayoritas penduduknya muslim sudah sepantasnya memberikan warna kehidupan yang mencerminkan nilai-nilai islami yang pada akhirnya menuju terciptanya masyarakat madani yang dapat memberikan perubahan secara signifikan. Di bidang perekonomian, dengan menerapkan karakteristik masyarakat madani antara lain; semangat pluralisme, sikap toleransi dan demokrasi diharapkan mampu membentuk mentalitas/ pribadi bangsa yang kuat dan tangguh dalam menghadapi berlangsungnya komunitas pasar global Asean saat ini, yang sering kita kenal dengan Masyarakat Ekonomi Asean (MEA).

\section{DAFTRA PUSTAKA}

\section{Abdul Wadud Nafis, Prospek Ahli Ekonomi Syariah dalam menghadapi}

${ }^{23}$ Tulus T.H Tambunan (2013), Masyarakat Ekonomi ASEAN..... hlm. 20 
ASEAN Economic Community, (Iqtishoduna Vol. 4 No. 1, April 2014)

Abuddin Nata, Kapita Selekta Pendidikan Islam, (Bandung: Angkasa, 2003)

Adnan Buyung Nasution, "Menuju Penguatan 'Civil Society", dalam Masyarakat Peradaban, (ILHAM, Semarang, 1997)

Aji Dedi Mulawarman, Masa Depan Islam: Dari Paradigma Menuju Metodologi, (Jurnal Ekonomi Imanensi, Vol. 1 No. 1, September 2013)

Deny Suito. Membangun Masyarakat Madani. (Centre For Moderate Muslim Indonesia: Jakarta. 2006)

Harun Nasution, Islam Rasional, (Mizan, Bandung, 1995)

Kuntowijoyo, Pengantar Ilmu Sejarah, (Yogyakarta: Yayasan Bintang Budaya. 1995)

M. Dawam Raharjo, Masyarakat Madani : Agama, Kelas Menengah dan Perubahan Sosial, (Pustaka LP3ES, Cet. ke - 1, Jakarta, 1999)

M. Dawam Raharjo, Sejarah Agama dan Masyarakat Madani dalam Membongkar "Mitos" Masyarakat Madani, (Pustaka Pelajar, Yogyakarta, 2001)

M. Solly Lubis, Umat Islam Dalam Globalisasi, ( Jakarta: Gema Insani Press. 1997)

M. Taufik Abdullah, "Di Sekitar Hasrat Ke Arah Masyarakat Madani”, dalam Membangun Masyarakat Madani Menuju Indonesia Baru Milenium Ketiga, (Pasca Sarjana UMM dan Aditya Media, Cet. ke - 1, Yogyakarta, 1999)

Nurcholish Madjid, "Masyarakat Madani dan Investasi Demokrasi : Tantangan dan Kemungkinan" dalam Ahmad Baso, Civil Society Versus Masyarakat Madani, Arkeologi Pemikiran "'Civil Society" Dalam Islam di Indonesia, (Pustaka
Hidayah,Cet. ke - 1, Bandung, 1999)

Sutari Imam Barnadib, Pengantar Ilmu Pendidikan Sistematis, (FIP-IKIP Yogyakarta, 2000)

Tulus T.H Tambunan, Masyarakat Ekonomi ASEAN; peluang dan tantangan bagi UKM Indonesia, (Policy Paper No: 15 tahun 2013)

https://fixguy.wordpress.com/makalah-masyarakat-madani/

Republika Online (2013), Indonesia Hanya Menduduki Peringkat Empat di ASEAN. 